The Geographical Journal of Nepal

Vol. 12: 101-118, 2019

Central Department of Geography,

Tribhuvan University, Kathmandu, Nepal

\title{
Commercial vegetable farming: Constraints and opportunities of farmers in Kirtipur, Nepal
}

\author{
Mohan Kumar Rai ${ }^{1}$, Pashupati Nepal ${ }^{1}$, Dhyanendra Bahadur Rai ${ }^{1}$, \\ Basanta Paudel ${ }^{*}$ \\ ${ }^{I}$ Central Department of Geography, Tribhuvan University, Kathmandu, Nepal; \\ ${ }^{2}$ Institute of Geographic Sciences and Natural Resources Research, CAS, Beijing \\ 100101, China
}

(*Corresponding Author: paudelb@igsnrr.ac.cn)

\begin{abstract}
Vegetable farming is one of the alternative sources of earning livelihood and becoming important agricultural practices for income generation and employment opportunities. This paper aims to analyze the constraints and opportunities of vegetable farmers in Kirtipur. Altogether 80 farm household survey were conducted in four major areas of Kirtipur. A total of 20 key informant interviews (KII) were also conducted to understand the perception of farm households on commercial vegetable farming. The result shows that around $94 \%$ of the total sampled farm households have leasehold farmland that has spread to different settlements of Kirtipur Municipality. Out of total leasehold farmers, $69 \%$ have written agreement with the landowner. The result also shows that the farmers cultivate vegetables in an average area of 5.67 ropani $\left(2884.49 \mathrm{~m}^{2}\right)$. Tomato (Solanum lycopersicum) and mushroom (Agaricus bisporus) are the primary vegetable products, whereas cauliflower (Brassica oleracea) and other green leafy vegetables are mostly cultivated as secondary vegetable products. Dug wells are the major sources of irrigation on vegetable farmland. Out of the total sampled farm households, about $42 \%$ of farmers are associated with farmers group and $37 \%$ have basic training on vegetable farming. Majority of farmers have savings from vegetable production and marketing. Despite few constraints like price fluctuation (81\%) and high middleman margins (71\%), vegetable farming in Kirtipur has many opportunities particularly being a major source income and livelihood (93\%), self-employment generation (87\%) and growing market demand (83\%). The opportunities in commercial
\end{abstract}


vegetable farming have continuously attracted the farmers in Kirtipur; however, the existing constraints has deprived farmers from their expected returns. Therefore, this paper recommends to portray possible options to promote opportunities and overcome the existing constraints to retain commercial vegetable farming as a sustainable source for farm households in Kirtipur.

DOI: $\underline{\text { http://dx.doi.org/10.3126/gjn.v12i1.23418 }}$

Keywords: vegetable farming, leasehold farmland, marketing, Kirtipur

\section{Introduction}

Vegetable farming with its higher farm-gate values and productivity stand as an important sector in agribusiness (Mariyono, 2017). Vegetable farming has become important part of agriculture in the surrounding of cities (De Zeeuw, Van Veenhuizen, \& Dubbeling, 2011). It has supported the livelihood of farmers through household subsistence farming to commercial scale (Van Veenhuizen \& Danso, 2007). Vegetable farming in the surrounding of city areas has been increased due to continuous rural to urban migration (Bryld, 2003).

In the vicinity of city, where agriculture is the occupation for livelihood and cash income, vegetable farming appears as one of the productive enterprises for cash generation (Rai et al., 2019). According to the report of MoAD (2017), the area, production and yield of vegetable is in increasing trend. Vegetable farming has become important sector of urban agriculture and regular income source for farmer practicing agriculture even in a small plot of land (Bhatta \& Doppler, 2010; De Zeeuw et al., 2011). Commercial farming has increasing trend in Nepal (Shrestha, Ojha, Pradhan, \& Joshi, 2018) and it shared a larger fragments of urban agriculture in Kathmandu Valley as the profitability attracted farmer day by day (Shrestha, Shrestha, \& Pandey, 2014). Lack of sufficient studies on commercial vegetable production has, however, narrowed the development of vegetable sector although, different initiative have been conducted in National level (Ghimire, Lamsal, Paudel, Khatri, \& Bhusal, 2018). Most of the youth after returning mostly from gulf countries switch their occupation to commercial farming and non-agricultural sector (Gautam, 2016) while coming back to Nepal. Furthermore, the increase in vegetable production can be attributed to the farmer's shift of cultivation trend from cereal crops like rice to vegetable crops due to high economic returns (Gurung, Thapa, Gautam, Karki, \& Regmi, 2016).

The vegetable sector has different opportunities and constrains like other agricultural sectors in Nepal even though it is a good source of income (Gurung et al., 2016). 
Identification of constraints and opportunities in vegetable farming is very crucial for the growth and development of the vegetable farming. Constraints indicate the hindering issues related to the vegetable farming and suggest the designing and implementation of appropriate interventions that address the constraints (Ruel and Levin, 2002). Contrarily, opportunities can help to find the potential market and areas where the poor farmers can participate as vegetable entrepreneurs (Emana and Gebremedhin, 2007). Being correlated both constraints and opportunities have to be studied together. The migration from different parts of the country has also changes in the agricultural land use (Paudel et. al., 2016; Paudel, Zhang, Yan, Rai, \& Li, 2019) and even in the agricultural practices in Kirtipur area. The vegetable farming can help farmers to generate cash even from a small area of land in a short period of time and helps farmers to improve their livelihood (Gurung et al., 2016). Vegetable farming emerges as an important source of living to farmers especially who have been migrated from different parts of the country in search of better livelihood. Those migrants have started vegetable farming as a source of income in the peripheries of urban areas (Rai et al., 2019).

Vegetable production and marketing have growing contribution to the national GDP by generating employment opportunities and poverty reduction to some extent (Pokhrel, 2010). Commercial vegetable farming has become an important asset of livelihood as it presumably support through food provision, income generation and employment (Bhatta \& Doppler, 2010; Asongwe, Yerima, \& Tening, 2014). Commercial vegetable farming can be a good method for poverty reduction in Nepal (Gurung et al., 2016). The profit from the commercial vegetable production can increased the income of the farm households (Mariyono, 2018). Vegetable farming is more beneficial than other cereal crops and offers job opportunities since it is more labor intensive (Bhatta \& Doppler, 2016; Dias, 2011). A farmer based organization can empower farmers and advantage to overcome the exploitation of farmers from the prospective buyers (Darkey, Dzoemku, Okorley, Gyimah, $\&$ Bluwey, 2014). The provision for possible support and training to the farmers can lead systematic farming with concerning food security (Asongwe et al., 2014).

Historically, agriculture was the main occupation of the people who reside in Kirtipur (Maharjan, 2014). Recently, people residing in the peripheries of Kirtipur are engaged in commercial vegetable farming as their main source of earning. The numbers of commercial vegetable farming has steadily been increasing due to the proximity to market center and its production potentiality (Rai et al., 2019). Most of the commercial vegetable farmers are leaseholders, who have been migrated from different parts of the country (Rai et al., 2019). Some of the previous studies, including Phulara (2010) and Rai (2017) stated about the vegetable farming in Kirtipur area which showed that the vegetable farming has positive impact on the livelihood and socio-economic condition 
of the farmer fulfilling the growing demand of local market and commercial scale. They concluded that farm households can take benefits from the vegetable farming by creating more opportunities and manage the constraints. In this context, this paper seeks to analyze the constraints and opportunities of commercial vegetable farming in Kirtipur.

\section{Study area}

Kirtipur Municipality is located in the south-western part of the Kathmandu Valley. The Municipality is bordered by Nagarjuna Municipality and Kathmandu Metropolitan City (KMC) to the north, Dakshinkali Municipality to the south, Bagmati River bordered with Lalitpur Metropolitan City (LMC) to the east and Chandragiri Municipality to the west. It covers a total area of $14.80 \mathrm{sq} \mathrm{km}$. It comprises 10 administrative wards. Most of the commercial vegetable pocket areas include four major sites: (1) Neyghal and Salyanthan, (2) Dhalpa, Jhulpokhari and Tusal, (3) Bhatkepati and Simlepokhari, and (4) Charghare, Pandeychhap, Chugaon and Bhutkhel (Figure 1).

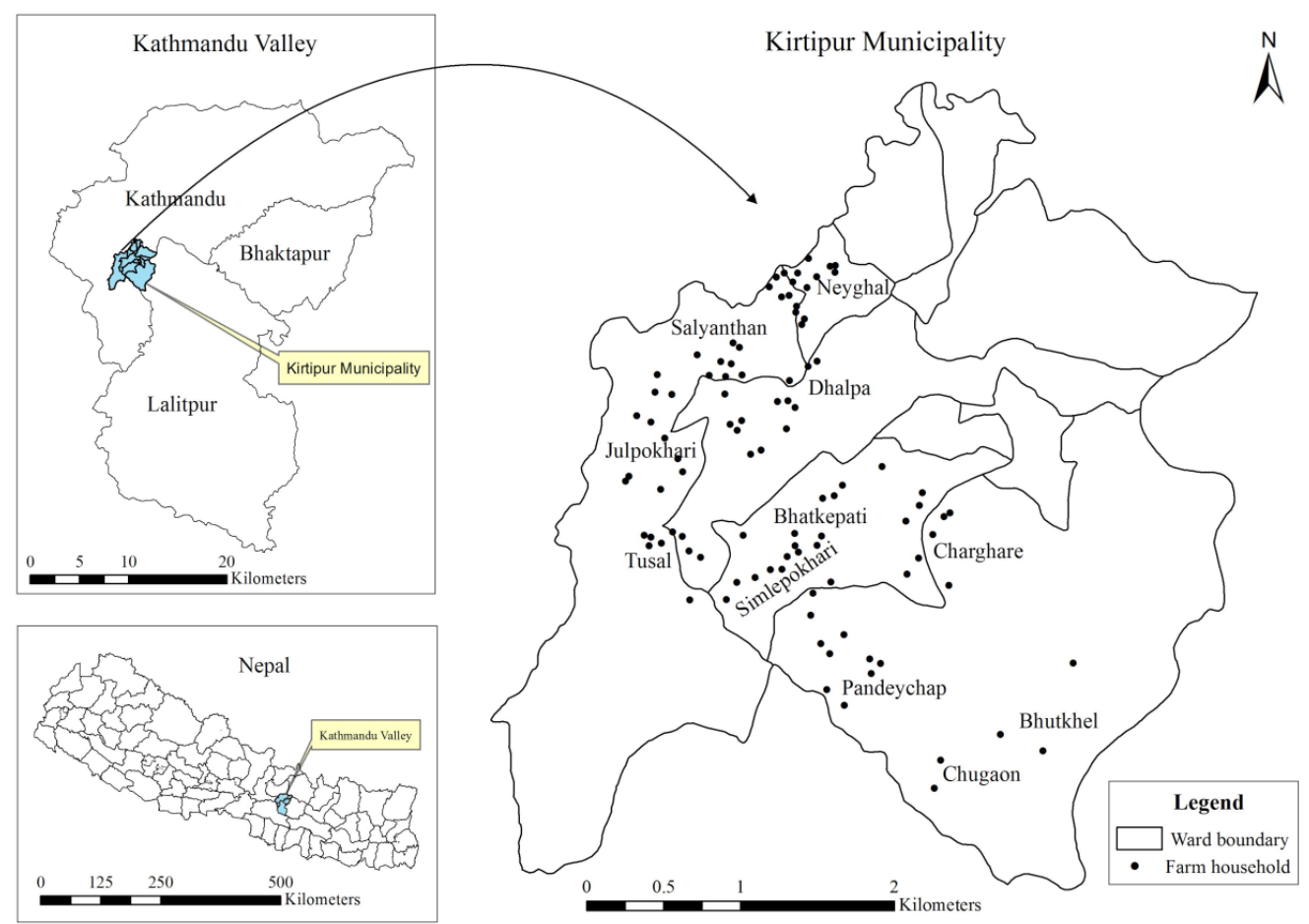

Figure 1: Location of the study area and sampled farm households 


\section{Data and methods}

This study is based on intensive field survey. In order to gather primary data and other information, household survey, key informant interviews (KIIs) and observation methods were adopted. The farm households were selected with purposive sampling method from different settlement sites of Kirtipur Municipality (Figure 1). Prior to household survey, a field observation was carried out to identify the tentative number of commercial vegetable farmers in the area. The area has about 242 commercial vegetable farmers dispersed over different settlement sites. The study has selected 33\% (80 farm households) of the total commercial vegetable farmers (242 farm households) for household survey. In order to represent the four settlement sites of the Kirtipur municipality, 20 farm households from each settlement were selected for household survey. The semi-structured questionnaires were administered to conduct household survey. Through household survey, the socioeconomic characteristics of vegetable farmers and other relevant information such as land ownership, major vegetables, affiliation, saving and expenditure, vegetable marketing and major opportunities and constraints of vegetable farming were obtained. In addition, 20 key informant interviews (KIIs), 5 from each settlement sites, were also conducted in order to extract the comprehensive information about the constraints and opportunities of vegetable farming. The key informant comprises of old age farmer, male and female local leaders, long experienced local and migrant leasehold farmers and youth vegetable farmers from different settlements. Furthermore, some informal discussions with local people and farmers have further benefited the study. All the acquired data were tabulated in Microsoft Excel. Descriptive statistics were used for summarization and interpretation and expressed through tables and figures.

\section{Result and discussion}

\section{Socio-demographic characteristics-of farmers}

The respondents for household level information were either head of the family or wellinformed member of household. Among the respondents, $75 \%$ of them were between the age group of 30-60 years, and $8 \%$ above 60 years, whereas nearly $17 \%$ were below the age of 30 years. Out of total surveyed farmers, $66 \%$ were male, while $34 \%$ were female respondents. Most of the respondent farmers (91\%) are literate. Among literate respondents, $60 \%$ have acquired secondary and higher level education. The average family size of sampled farm household is 6.1 , where the majority of households (57\%) consist of 1-5 members and rests have 6-10 members. Most of the families have challenges to the limited earnings particularly for leasehold farmers; however, the 
larger number has advantage on the labor pool. Around $34 \%$ of the respondent farmers were the youths who had been to different gulf countries in search of better earning. After returning to Nepal, they have started vegetable farming as an alternative source of livelihood in the urban-fringe of Kiritpur. During the field survey, it was found that they were engaged in agriculture before migration to this place, and converted their traditional occupation to commercial vegetable farming when they migrated to Kirtipur. These findings also support as general trend in line with the finding from the study conducted by Gautam in 2016 .

The annual income of the farm household from the commercial vegetables marketing ranges from less than 100 thousands NPR to more than 500 thousands NPR (Figure 2a). Besides the investment on different inputs (seed, plastic tunnel, pesticides, fertilizer, manure, transportation), most of the farmers have substantial earning from vegetable production and marketing. Vegetable farming has therefore, become a major source of income and self-employment to the farmers of study area.

The longevity of farming started can have the advantage on the experience on farming. The survey also exposed that most of the farmers have entered to commercial vegetable farming during last six years although some farmers have more than ten years of farming experiences. Large numbers of farmers (29\%) have the experience between 2-4 years whereas small portion of farmers have 8-10 years of experience on commercial vegetable farming. The survey also reveals that the number of new vegetable farmers are in increasing trend but are not sustained for prolong period (Figure 2b).

In addition to cultivating vegetables, farmers also keep livestock in the study area (Figure 3). Livestocks are inseparable part of agriculture. Farmers domesticate them for manure and additional source of income for vegetable farmers in Kirtipur. There has been two way advantages on vegetable farming and livestock as the vegetable residuals are properly utilized for fodder for most of the livestock. In return, livestock manure can be used for organic purposes which induced the vegetable quality. 


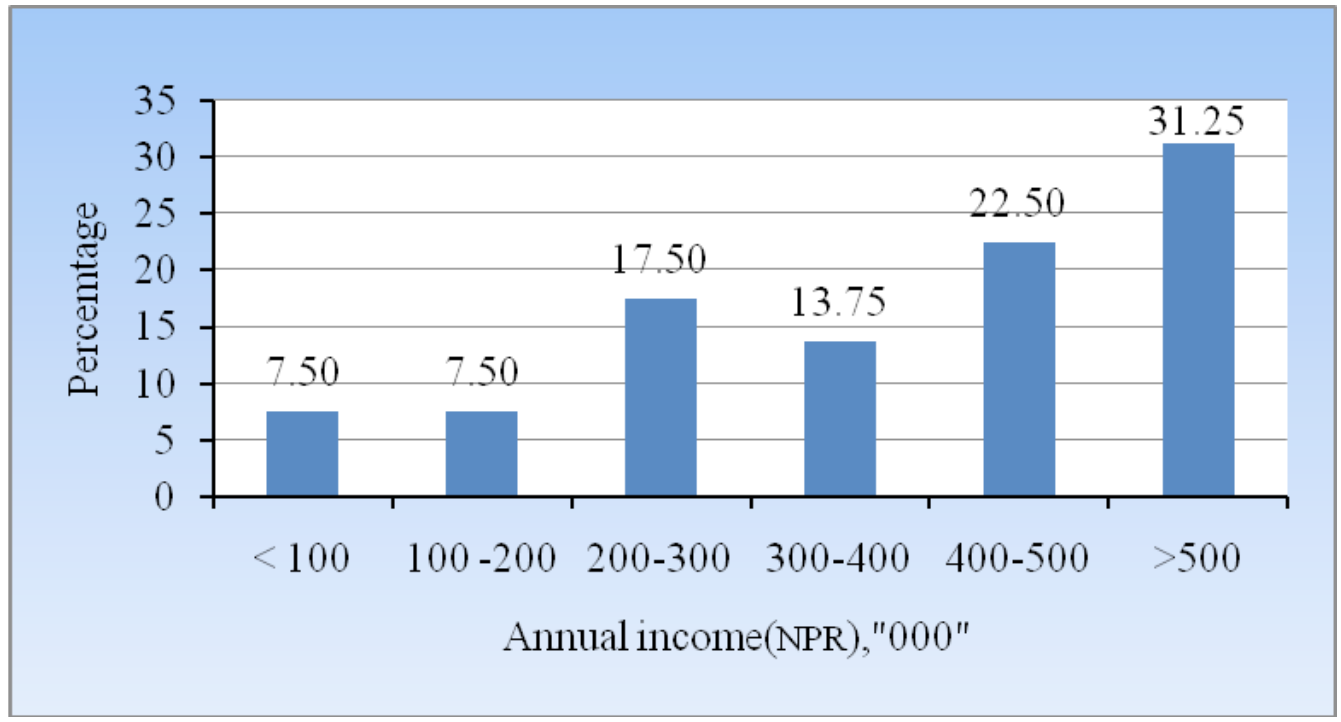

(a)



(b)

Figure 2: a) Farmer's annual income ('000' NPR) and b) Year of vegetable farming. 


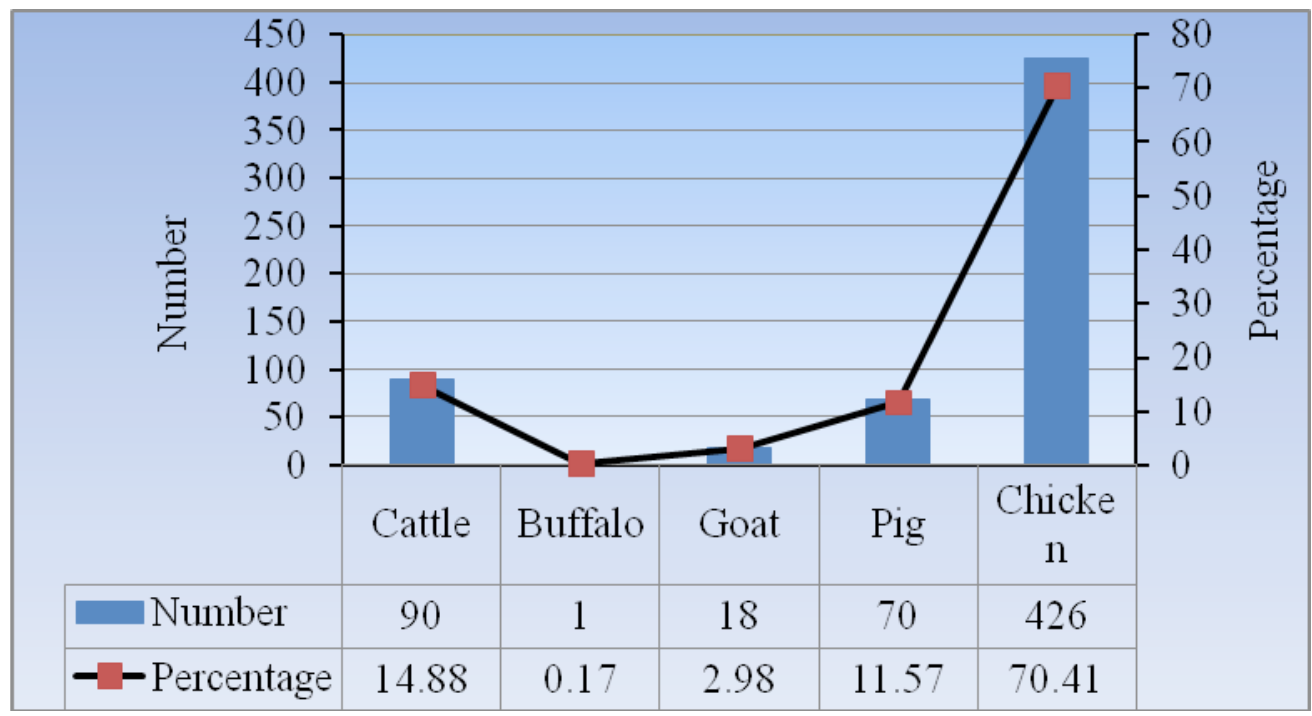

Figure 3: Number of of livestock keeping

\section{Ownership of farmland and access to facilities}

The result from the field survey shows that most of the farmers (94\%) have leasehold farmland out of which $69 \%$ have written agreement at least for five years. Lack of written agreement between two parties (landowner and leaseholder) deprived farmers from possible subsides. Almost all vegetable farmlands were used for rice field in the past which is replaced by commercial vegetable farming through leasehold practices in this area. During discussion with one of the local farmers as key informant, he expressed as follows-

The number of leaseholders is increasing day by day due to commercial farming of vegetables. Rice farming is being replaced by vegetable farming specially tomato cultivation under plastic tunnel. Local people have drop down rice farming due to lack of agricultural labor. However, the landowners have substantial earning from lease holding land. Most of the leaseholders are migrants.

Hariom Maharjan, aged 62 from Dhalpa, Kirtipur

The study area has different sources of water for the utilization on agricultural sector (Maharjan, 2014). However, higher percentages of the vegetable farmers are relying on ground water through dug wells followed by stream water nearby for irrigation source as there is lack of proper irrigation system. Only $10 \%$ of farmers have access of canal whereas nearly $8 \%$ farmers used to store rain water and sewage water for irrigation in their farmland (Table 1). 
Kirtipur area has accessibility of road network either through blacktopped, gravel or track road (Maharjan, 2014). One of the reasons behind the farmer's attraction on vegetable farming is the road accessibility in the area and transportation services to market. Thus, all the surveyed farm households have access of road close to their farmland. Most of the farmlands were connected by gravel road and $11 \%$ of farmlands are close to blacktopped road whereas $16 \%$ of farmlands are connected by earthen road only (Table 1).

Table 1: Type and access to resources

\begin{tabular}{|l|r|}
\hline Variables & \multicolumn{2}{|c|}{ Percentage } \\
\hline Land Ownership & 6.50 \\
\hline Own land & 93.50 \\
\hline Leasehold & $\mathbf{1 0 0}$ \\
\hline Total & 68.75 \\
\hline Written agreement with landowner & 60.00 \\
\hline Major Source used for irrigation & 22.50 \\
\hline Dug-well (Inar) & 10.00 \\
\hline Streams(supply with plastic pipes) & 7.50 \\
\hline Canal & $\mathbf{1 0 0}$ \\
\hline Pond (colleting rainwater and sewage) & 11.25 \\
\hline Total & 72.50 \\
\hline Road & 16.25 \\
\hline Blacktopped & $\mathbf{1 0 0}$ \\
\hline Gravel & \\
\hline Earthen & \\
\hline Total & \\
\hline
\end{tabular}

Source: Field survey, 2019

\section{Saving and expenditure from major vegetable production}

Tomato (Solanum lycopersicum) is a major vegetable production which is cultivated as a primary commercial vegetable in Kirtipur. Due to high market potentialities tomato emerge as one of the important vegetable (Ghimire, Kandel, Aryal, \& Bhattarai, 2017). Mushroom (Agaricus bisporus) and green leafy vegetable have very little exposure as commercial farm products. However, Cauliflower (Brassica oleracea) and other green leafy vegetables are secondary vegetable production by most of the farmers (Table 2). The farmers cultivate tomato once in a year and nearly $31 \%$ farmers have practiced intercropping tomato either with cauliflower or other green leafy vegetables. The trend in vegetable gardening in Machchhegaun of Kirtipur is somehow different where cauliflower remained the main vegetable products (Rai, 2017). The study revealed that slightly more than one third of the farmers borrowed loan from different sources. The study also found that most the vegetable farmers borrowed loans from individuals and 
cooperatives for vegetable farming (Table 2). A reason behind farmers' less inclination towards bank loans is due to the lack of agreement paper between farmers and landowners. However, the affiliation of farmers with local farmers group and other cooperatives have opened the door for borrowing loan for commercial vegetable farming and saving on monthly basis.

The survey revealed that the majority of farmers (59\%) have investment for agricultural inputs. Agricultural inputs include the cash for lease, construction materials (plastic tunnel and bamboo fencing especially for tomato), vegetable seeds, labor wage, manure, fertilizer, pesticides, irrigation, and transportation cost. Among the top three expenditures claimed by farmers, children education is ranked in second position after agricultural inputs. The migrant farmers tend to continue their agriculture farming while educating their children in reputed schools in the Kathmandu Valley. As a result, most of the farmers send their children to private schools which are more expensive than the community ones.

Table 2: Saving and expenditure from major vegetable production

\begin{tabular}{|l|r|}
\hline Variables & \multicolumn{2}{|}{ Percentage } \\
\hline Major vegetable cultivation & 92.50 \\
\hline Tomato (Solanum lycopersicum) & 5.00 \\
\hline Mushroom (Agaricus bisporus) & 2.50 \\
\hline Green leafy vegetable & 100.00 \\
\hline Total & 41.25 \\
\hline Secondary vegetable cultivation & 20.00 \\
\hline Cauli flower (Brassica oleracea) & 61.25 \\
\hline Mixed green leafy vegetable & 36.25 \\
\hline Total & 5.00 \\
\hline Loan borrowed for vegetable farming & 16.25 \\
\hline Bank & 15.00 \\
\hline Cooperatives & 62.50 \\
\hline Individuals & 7166 \\
\hline Saving from vegetable farming & 58.75 \\
\hline Average savings per month (NPR) & 23.75 \\
\hline Major expenditure & 17.50 \\
\hline Agriculture inputs & 100.00 \\
\hline Children's education & \\
\hline Consumables & \\
\hline Total & \\
\hline
\end{tabular}

Source: Field survey, 2019 


\section{Marketing of vegetables}

The vegetable marketing channel in Kirtipur area is shown in Figure 4, which reveals that most of the farmers $(76 \%)$ sell their products to collection and distribution center through contractors as middlemen. Due to perishability of vegetables especially tomato, the farmers directly sell their products to contractor as the area have lack of collection and storage center. The survey also revealed that around $18 \%$ of farmer sells vegetables in nearby local market (Naya bazar \& Bagbhairav) either through local vendor or by farmers on their own carrying in bamboo baskets (Doko). Furthermore, only 6\% of surveyed farmers used to sell their vegetable products from locality (Figure 4). This marketing channel is quite similar to the findings of Rai et al., (2019) however, contradicts with the findings of Shrestha et al., (2014) in the Kathmandu Valley. During the discussion, most of the vegetable farmers admitted that they have not been able to obtain expected return from the vegetable marketing without proper marketing channels. The similar types of findings were derived by Thapa and Dhimal (2017) in the case of horticulture as a whole.

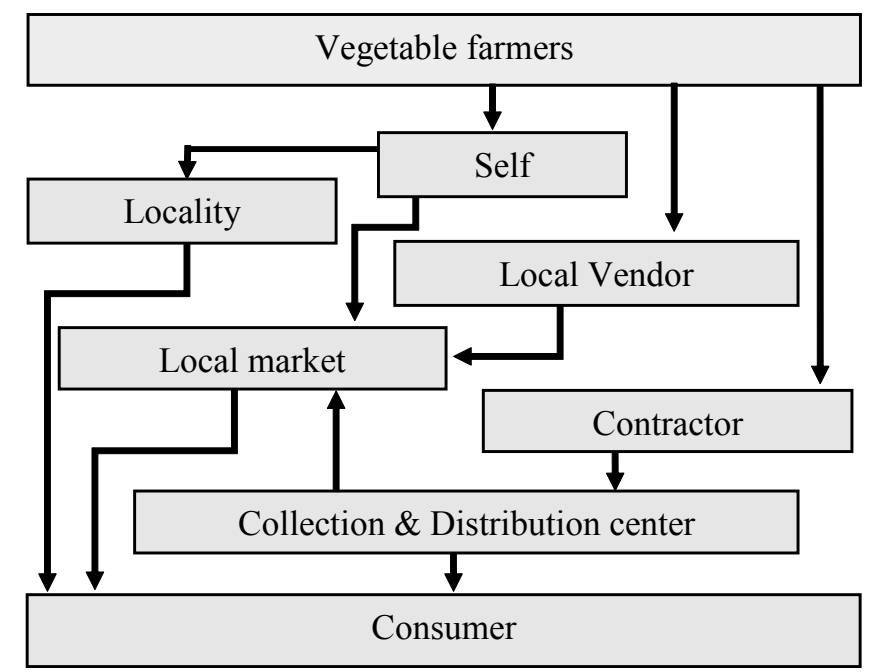

Figure 4: Vegetable marketing channel in Kirtipur

\section{Opportunities and constraints of commercial vegetable farming}

The cultivation of vegetable in commercial manner can uplift farmers' economic condition (Mariyono et al., 2017). In the urban fringe area of Kirtipur, the number of vegetable farmers has been increasing due to its profitability and publicity of commercial 
vegetable farming. Most of the farmers in Kirtipur have responded that commercial vegetable farming is an important source of income and securing livelihood (Table 3). The study by Phulara (2010) and Rai (2017) has also illustrated that vegetable farming in Kirtipur has contributed to sustainable livelihood. The finding of the recent study conducted by Rai et al., (2019) also mentioned that the vegetable farming is very crucial to livelihood of farmers in peri-urban areas in Kathmandu Valley. Due to the reason of agricultural background of most of the migrated family they have chosen vegetable farming as the alternative source of income in Kirtipur. Similarly, the survey revealed that the chance of self-employment remained as the second major opportunity of vegetable farming (Table 3). Generally, the vegetable farming is more labor intensive than other forms of agriculture hence it needs more involvement of farmers and more laborers have chances to get employment in line with argument of Dias (2011), Bhatta \& Doppler (2016). In the meantime, the advantage of year round production and growing demand in urban markets has added more opportunities to the vegetable farmers (Table 3).

Likewise, the accessibility of road network for transportation from farmland to market centre and irrigation are added value for the farmers in Kirtipur whereas a study conducted by Paudel and Adhikari (2018) in Dhading district revealed that lack of transportation facility emerges as main constraints of vegetable marketing. The farmers have advantage to be located in Kathmandu Valley as one of the most populated areas in the country which have proximity of different market centers within the Valley. Moreover, the involvement in the cooperatives and farmers groups and the provision of training are also understood as the opportunities of vegetable farming in Kirtipur. A study by Darkey et al., (2014) also recommended that farmers affiliation to different groups is very important for their empowerment. The affiliation would further improve the management of common resources to increase farmers' productivity and income (Suvedi, Ghimire \& Kaplowitz, 2017). Meanwhile commercial vegetable farming has become one of the major alternatives to the foreign labor migration. One of the farmers shares his experience in this light:

It has been six years of my involvement in vegetable farming. I have started this occupation since I came back from Lebanon, worked as a migrant worker for couple of years. Now I cultivate 6 ropani of lease farmland. I am earning more than five hundred thousand rupees annually. Deploying myself in this occupation, I am running my family efficiently and most importantly investing on children's education too. Recently I have also initiated a farmers group called Kishan Chautari Nepal for the betterment of farmers in Nepal.

Narayan Singh Khadka, 38, a leader farmer from Pandeychhap, Kirtipur, originally from Gulmi district 
Table 3: Opportunity and constraints of commercial vegetable farming $(n=80)$

\begin{tabular}{|l|r|l|r|}
\hline \multicolumn{1}{|c|}{ Opportunities } & Coverage & \multicolumn{1}{c|}{ Constraints } & Coverage \\
\hline Source of income and livelihood & 92.50 & Frequent price fluctuation & 81.00 \\
\hline Self-Employment & 86.75 & High middleman margins & 71.25 \\
\hline Growing market demand & 83.00 & More inputs & 58.75 \\
\hline Year round production of vegetables & 81.00 & Delay in payment by contractors & 51.00 \\
\hline Accessibility of road and irrigation & 70.00 & Vegetable Diseases & 40.00 \\
\hline Farmers high motivation & 68.00 & Inadequate Quality of Seeds supply & 40.00 \\
\hline Access to financial institutions & 62.50 & Increase in leasehold rate & 35.00 \\
\hline Proximity to market & 45.25 & Denial of leasehold agreement & 31.25 \\
\hline Involvement in cooperatives & 41.25 & Lack of proper irrigation system & 30.00 \\
\cline { 1 - 3 } Training on vegetable farming & 34.00 & $\begin{array}{l}\text { Lack of collection center and cold } \\
\text { storage }\end{array}$ & 23.75 \\
\cline { 1 - 3 } Alternative for foreign labor migration & 33.75 & &
\end{tabular}

Source: Field survey, 2019

The commercial vegetable sector has been facing several constraints in Kirtipur area. The finding reveals that the frequent price fluctuation has been one of the major challenges in vegetable farming (Table 3) and it is also mentioned by Thapa \& Dhimal (2017) and Pokhrel (2010). The results are also similar with the finding of study conducted by Kumar, Chauhan, Tanwar and Grover (2018), where the price fluctuation remained as second constraints along with lack of support price. A high margin of profit taken by middleman is another crucial constraint in commercial vegetable farming in the study area. The findings of Shrestha, et al., (2014) have also noted that the price instability and higher middleman margins were the most critical constraints in vegetable farming. A large share benefit from vegetable marketing is retained by middleman (Bichauliya) becoming a parasite of farmers (Bhattarai, Subedi, Gautam \& Chauhan, 2017). According to Mariyono et al., (2018), the role of middleman has been very crucial in price instability. The price fluctuation and market monopoly by the middleman are also discussed by Rai et al., (2019) as major problems while conducting similar study in Kathmandu valley. Agreeing with the conclusion of Kumar, Roy and Mukherjee (2018) the market monitoring and frequent guidance to the vegetable growers could be one of the solutions to protect farmers from marketing exploitation by the middleman.

Meanwhile, the vegetable diseases tend to be another notable constraint in vegetable farming with losses in production and depriving farmers from expected profits (Table 3 ). Vegetable diseases has also become a major challenges which discrete farmers 
from good returns (Shrestha, 2018; Shrestha, Prajapati \& Mahato, 2014). According to Joosten, Dijkxhoorn, Sertse, \& Ruben (2015) the vegetable diseases are one of the key challenges which resulted in maximum pre-harvest loss. The increase in farming inputs is significantly associated with the emergence of diseases which added extra financial burdens to the farmers. In accord to the study by Jha et al., (2016) lack of proper irrigation system has also impacted in the agricultural returns and agreeing with the finding of Timalsina and Shivakoti (2018), deficient in supply of quality seeds are also the constricting factor for vegetable production (Table 3 ).

The lack of written agreement between leaseholder and the landowner has deprived the farmers in Kirtipur from possible subsidies either from government or NGOs. This condition was also mentioned in similar studies by Rai et al., (2019). In addition to that, unexpected increment in the leasehold amount annually has becoming a trend in vegetable farmland where the leaseholder suffers most. Kirtipur area has the similar situation relating to the study conducted by Phukan, Avasthe, Lepcha, and Singh (2018) and Sisay, (2018). The lack of infrastructural assets like the proper marketing yards and collection centers with cool storage system are the constraints which bound farmers to sell their products through contractors in other places.

Common voices of farmers during KII in regards to constraints of vegetable farming are follows:

Vegetable price are very unpredictable, especially tomato which we cultivate more as commercial vegetable. Even if we have good production we are not benefited as middleman does. They can earn more than five times, a farmers can earn annually. On the other side, vegetable diseases lowered the production and sometimes the condition remains unmanageable to have the expected returns.

\section{Conclusion}

Commercial vegetable farming is one of the main economic activities of the farmers in Kirtipur. Most of the farms are owned by migrant farmers as a leaseholder. The farmers have great attention due to the increasing urban demand, its profitability and accessibility of road and growing market demand. Commercial vegetable farming in Kirtipur has both opportunities and constraints in production and marketing phase. Commercial vegetable farming has more opportunities than the constraints in Kirtipur area. Most of the constraints are related to the post- harvest process like marketing of vegetables where the frequent price fluctuation benefited the middleman most. Therefore, further steps on the basis of constraints and opportunities identified by this study could prove more effective in order to preserve commercial vegetable farming as an important agricultural $\|114\|$ 
sector in the study area. With proper management of marketing segment could greatly contribute for development of commercial vegetable sector. Furthermore, commercial vegetable farming could be a module of socio-economic development. So, further study could be focus to portray possible options to promote opportunities and overcome the existing constraints to retained commercial vegetable farming as a sustainable source for farm households in Kirtipur.

\section{Acknowledgement}

The authors would like to appreciate and thank to all the vegetable farmers of Kirtipur, who have participated in this research with sharing important information during informal discussion, KII and household survey.

\section{References}

Asongwe, G. A., Yerima, B. P., \& Tening, A. S. (2014). Vegetable production and the livelihood of farmers in Bamenda Municipality, Cameroon. International Journal of Current Microbiology abd Applied Science,3(12): 682-700.

Bhatta, G. D., \& Doppler, W. (2016). Smallholder peri-urban organic farming in Nepal: A comparative analysis of farming systems. Journal of Agriculture, Food Systems, and Community Development, 1(3): 163-180. https://doi.org/10.5304/ jafscd.2011.013.002

Bhatta, G. D., \& Doppler, W. (2010). Socio-economic and environmental aspects of farming practices in the peri-urban hinterlands of Nepal. Journal of Agriculture and Environment, 11: 26-39.

Bhattarai, D. R., Subedi, G. D., Gautam, I. P., \& Chauhan, S. (2017). Post harvest supply chain study of carrot in Nepal. International Journal of Horticulture, 7(26): 239245. http://dx.doi.org/10.5376/ijh.2017.07.0026

Bryld, E. (2003). Potentials, problems, and policy implications for urban agriculture in developing countries. Agriculture and Human Values, 20(1):79-86. https://doi. org/10.1023/A:1022464607153

Darkey, S. K., Dzoemku, B. M., Okorley, E. L., Gyimah, N. A., \& Bluwey, F. A. (2014). Contribution of urban vegetable production to farmer's livelihood: A case of the Kumasi Metropolis of Ashanti region of Ghana. Scientific Papers Series Management, Economic Engineering in Agriculture and Rural Development, 14(1): 77-82. 
De Zeeuw, H., Van Veenhuizen, R., \& Dubbeling, M. (2011). The role of urban agriculture in building resilient cities in developing countries. The Journal of Agricultural Science, 149(1): 153-163. https://doi.org/10.1017/S0021859610001279

Dias, J. (2011). World importance, marketing and trading of vegetables. Acta Horticulturae, 921:153-169. https://doi.org/10.17660/ActaHortic.2011.921.18

Emana, B., \& Gebremedhin, H. (2007). Constraints and opportunities of horticulture production and marketing in eastern Ethiopia. Dry Lands Coordination Group (DCG) Report No. 46.

Gautam, A. (2016). International migration and remittance in Nepal. Journal of Population and Development Issues, 92-103.

Ghimire, D., Lamsal, G., Paudel, B., Khatri, S., \& Bhusal, B. (2018). Analysis of trend in area, production and yield of major vegetables of Nepal. Trends in Horticulture, 1: 1-11. DOI: $10.24294 /$ th.v1i2.914

Ghimire, N., Kandel, M., Aryal, M., \& Bhattarai, D. (2017). Assessment of tomato consumption and demand in Nepal. Journal of Agriculture and Environment, 18: 83-94. https://doi.org/10.3126/aej.v18i0.19893

Gurung, B., Thapa, R., Gautam, D., Karki, K., \& Regmi, P. (2016). Commercial vegetable farming: An approach for poverty reduction in Nepal. Agronomy Journal of Nepal, 4: 92-106. https://doi.org/10.3126/ajn.v4i0.15518

Jha, A. K., Malla, R., Sharma, M., Panthi, J., Lakhankar, T., Krakauer, N. Y., Pradhanang, S. N., Dahal, P., Shrestha, M. N. (2016). Impact of irrigation method on water use efficiency and productivity of fodder crops in Nepal. Climate, 4 (1): 4. doi. org/10.3390/cli4010004

Joosten, F., Dijkxhoorn, Y., Sertse, Y., \& Ruben, R. (2015). How does the fruit and vegetable sector contribute to food and nutrition security? LEI Wageningen: the Netherlands.

Kumar, P., Chauhan, R. S.,Tanwar, N., \& Grover, R. K. (2018). Status and constraints in vegetable cultivation under polyhouse in Haryana. Advances in Bioresearch, 9(2): 61-66. doi: 10.15515/abr.0976-4585.9.2.6166

Kumar, S., Roy, M., \& Mukherjee, A. (2018). Marketing behaviour of vegetable growers in Uttarakhand hills. Journal of Community Mobilization and Sustainable Development, 13(1): 68-74.

Maharjan, G. R. (2014). Newar Indigenous Knowledge of Water Resources Management in Kirtipur. Kathmandu, Nepal: NFDIN. 
Mariyono, J., Dewi, H. A., Daroini, P. B., Latifah, E., Zakariya, A. Z., \& Afari-Sefa, V. (2018). Marketing aspects of vegetables: Comparative study of four regions in East Java and Bali. Agriekonomika, 7(1): 46-56. doi: 10.21107/agriekonomika.v7i2.3410

Mariyono, J. (2017). Profitability and determinants of smallholder commercial vegetable production. International Journal of Vegetable Science, 24(3): 274-288. https://doi. org/10.1080/19315260.2017.1413698

Mariyono, J., Kuntariningsih, A., Dewi, H. A., Latifah, E., Daroini, P. B., Negoro, A. A., Afari-Sefa, V., Luther, G. (2017). Pathway analysis of vegetable farming commercialization. Economic Journal of Emerging Markets, 9(2): 115-124.

MoAD (2017). Statistical information of Nepalese Agriculture, 2015/16. Kathmandu Ministry of Agricultural Development, Monitoring, Evaluation and Statistics Division Agri Statistics Section, Singh Durbar.

Paudel, B., Gao, J., Zhang, Y., Wu, X., Li, S., \& Yan, J. (2016). Changes in cropland status and their driving factors in the Koshi River basin of the Central Himalayas, Nepal Sustainability, 8 (9): 933. https://dx.doi.org/10.3390/su8090933

Paudel, B., Zhang, Y., Yan, J., Rai, R., \& Li, L. (2019). Farmers' perceptions of agricultural land use changes in Nepal and their major drivers. Journal of Mountain Environment, 235: 432- 441. https://doi.org/10.1016/j.jenvman.2019.01.091

Paudel, P., \& Adhikari, R. K. (2018). Economic analysis of tomato farming under different production system in Dhading district of Nepal. Nepalese Journal of Agricultural Sciences, 16: 217-224.

Phukan, P., Avasthe, R., Lepcha, B., \& Singh, R. (2018). Marketing behaviour of vegetable growers in East Sikkim. Journal of Krishi Vigyan, 6(2):157-162. http://dx.doi. org/10.5958/2349-4433.2018.00017.

Phulara, N. P. (2010). Changing livelihood patterns of vegetable farmers: A case study of Charghare settlement of Kirtipur Municipality, Kathmandu. Unpublished Master Degree thesis, submitted to Central Department of Geography T. U. Kathmandu, Nepal.

Pokhrel, D. M. (2010). Comparison of farm production and marketing cost and benefit among selected vegetable pockets in Nepal. The Journal of Agriculture and Environment, 11: $10-25$.

Rai, D. B. (2017). Vegetable gardening and marketing in Kirtipur area of Kathmandu. Nepalese Journal of Development and Rural Studies, 14(1-2): 28-35. https://doi. org/10.3126/njdrs.v14i1-2.19645 
Rai, M. K., Paudel, B., Zhang, Y., Khanal, N. R., Nepal, P., \& Koirala, H. L. (2019). Vegetable farming and farmers' livelihood: Insights from Kathmandu Valley, Nepal. Sustainability, 11(3): 889. https://doi.org/10.3390/su11030889

Ruel, M. T., \& Levin, C. E. (2002). Food-based approaches for alleviating micronutrient malnutrition: An overview. Journal of Crop Production, 6 (1-2): 31-53. https://doi. org/10.1300/J144v06n01_05

Shrestha, G. (2018). Disease suppressiveness characteristics of vegetable growing soils in Kathmandu valley. Nepalese Journal of Agricultural Sciences, 16: 199-208.

Shrestha, S., Ojha, R. B., Pradhan, N. G., \& Joshi, B. D. (2018). Performance of tomato with organic manures in plastic tunnel. Journal of Nepal Agricultural Research Council, 4(28): 1-6. https://doi.org/10.3126/jnarc.v4i1.19681

Shrestha, G., Prajapati, S., \& Mahato, B.N. (2014). Plant diseases and their management practices in commercial organic and conventional vegetable farms in Kathmandu valley. Nepalese Journal of Agricultural Sciences, 12: 129-141.

Shrestha, K., Shrestha, G., \& Pandey, P. R. (2014). Economic analysis of commercial organic and conventional vegetable farming in Kathmandu valley. Journal of Agriculture and Environment, 15: 58-71. https://doi.org/10.3126/aej.v15i0.19816

Sisay, M. A. (2018). Assessment of challenges in export marketing: The case of Ethiopian vegetable and fruit commercial growers. iBusiness, 10:1-20. https://doi.org/10.4236/ ib.2018.101001

Suvedi, M., Ghimire, R., \& Kaplowitz, M. (2017). Revitalizing agricultural extension services in developing countries: Lessons from off-season vegetable production in rural Nepal. Journal of the International Society for Southeast Asian Agricultural Sciences,23(1): 1-11

Thapa, M. B., \& Dhimal, S. (2017). Horticulture development in Nepal: Prospects, challenges and strategies. Universal Journal of Agricultural Research, 5(3): 177-189. DOI: 10.13189/ujar.2017.050301

Timalsina, K. P., \& Sivakoti, G. P. (2018). Vegetables production and marketing: practice and perception of vegetable seed producers and fresh growers in Nepal. Agriculture and Food Security, 7(11): https://doi.org/10.1186/s40066-018-0161-9

Van Veenhuizen, R., \& Danso, G. (2007). Profitability and sustainability of urban and periurban agriculture (Vol. 19): Food \& Agriculture Orgnization . Rome, Italy. 